\section{Helhetlig om psykoterapi ved hjerneskader}

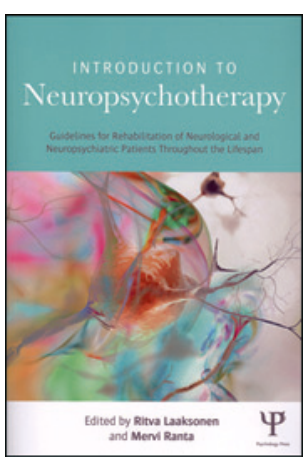

Ritva Laaksonen, Mervi Ranta, red. Introduction to neuropsychotherapy Guidelines for rehabilitation of neurological and neuropsychiatric patients throughout the lifespan. 259 s, ill. Hove: Psychology Press, 2013. Pris GBP 40

ISBN 978-1-84872-623-9

Denne boken om nevropsykoterapi er skrevet av klinisk orienterte nevropsykologer som arbeider med rehabilitering av pasienter med nevrologiske og nevropsykiatriske lidelser. For å optimalisere behandlings- og rehabiliteringstilbudet til denne pasientgruppen sikter forfatterne på å ta i bruk kunnskap både fra nevropsykologien og psykoterapien til det beste for pasientene.

I de 12 kapitlene tar forfatterne for seg alt fra nevropsykologiske utredninger, hjernens utvikling, effekten hjerneskader har på emosjonell regulering, hvordan engasjere barn med hjerneskader i en psykoterapeutisk prosess, og nevropsykoterapi ved ulike utviklingsforstyrrelser. Selv om det er ulike forfattere som står bak hvert kapittel, er boken stramt redigert og fremstår som helhetlig.

Illustrasjonene består av rekke selvforklarende figurer og tabeller som understøtter teksten. Viktige referanser er gjengitt etter hvert kapittel. Det burde vært en liste over forkortelser i begynnelsen. Mange forkortelser som blir brukt, er ikke selvforklarende for lesere som ikke er helt inne i dette feltet. For eksempel blir ikke ABI (Aquired Brain Injury) forklart før i kapittel 8. Det er ikke angitt noen spesifikk målgruppe, men boken synes å være myntet på leger og psykologer som arbeider med habilitering/rehabilitering av personer med nevrologiske og nevropsykiatriske lidelser.

Teksten er relativt lettlest og integrerer kunnskap fra nevropsykologien med ulike psykoterapeutiske retninger. De psykodynamiske og kognitive psykoterapeutiske retningene har fătt mest plass. Det er lett å tenke seg at en slik tilnærming til et felt lett kunne blitt fragmentarisk og rotete. Slik blir det ikke. Redaktørene har klart å få dette til å fremstå som en helhet hvor ulike teoretiske begreper fra de ulike retningene blir satt $\mathrm{i}$ en fin sammenheng med illustrative pasienthistorier og terapiforløp. Her blir utfordringer med motstand og terapeutisk allianse forklart ut fra både Freuds psykoanalyse og den nevrologiske/nevropsykiatriske lidelsen. Viktigheten av psykoedukasjon blir også grundig beskrevet.

Boken inneholder mye nyttig kunnskap, og det viktigste bidraget er kanskje å integrere biologiske, psykologiske og sosiale faktorer $\mathrm{i}$ behandlingen av personer med hjerneskader. Spesielt tror jeg den vil være nyttig for leger innen CL-psykiatri, nevrologi og både voksenpsykiatri og barne- og ungdomspsykiatri. Boken favner imidlertid så bredt $\mathrm{i}$ temaer at også andre yrkesgrupper, for eksempel sykepleiere som arbeider med disse pasientgruppene, kan ha glede av den.

Jan Ivar Røssberg

Professor, Institutt for klinisk medisin

Universitetet i Oslo

\section{Variert oversikt over aktuell yrkesepidemiologi}

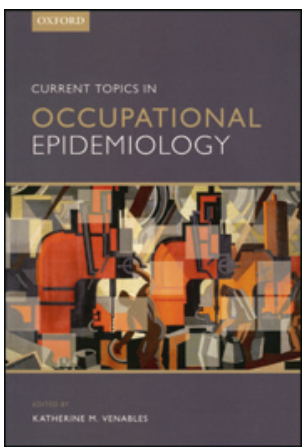

Katherine M. Venables, red

Current topics in occupational epidemiology 288 s, tab, ill. Oxford: Oxford University Press, 2013. Pris GBP 35 ISBN 978-0-19-968390-1

Dette er ikke en lærebok, men en artikkelsamling som omhandler et bredt utvalg av emner innen yrkesepidemiologi, i alt 19 kapitler. Redaktøren er engelsk, men forfatterne er internasjonale. Mange av disse er anerkjente eksperter, og artiklene virker gjennomgående godt oppdatert. Utvalget av emner kan imidlertid virke noe tilfeldig. Målgruppen er ikke klart definert, men mange artikler vil trolig interessere så vel forskere som arbeidsmedisinere og samfunnsmedisinere.

En vesentlig del omhandler forskningsmetode. Disse artiklene har generell interesse. Forholdet mellom frekventistisk og bayesiansk statistikk har vært uavklart innen epidemiologi. De fleste epidemiologer er erklærte frekventister, men diskuterer i praksis sine funn i lys av tilgjengelig kunnskap. Forfatterne Pearce og Corbin mener derfor at de samme epidemiologene i praksis er $k v a-$ litative bayesianere. De argumenterer godt for at litteraturen vil ha nytte av å inkorporere bayesianske metoder i metode- og resultatavsnittene. Smith og Kriebel presenterer fire hovedtyper av biologiske sykdomsmodeller for å analysere sammenhenger mellom dose og respons. Dette kan være en vei å gå for å avdekke mer spesifikke årsakssammenhenger som kan danne grunnlag for mer målrettet forebygging. Artiklene om systematiske oversikter innen arbeidsmedisin, risikoanalyse og økonomisk analyse av forebyggende tiltak er også informative. Praktisk nyttige er også artiklene som omhandler systemer for overvåking av arbeidsrelaterte sykdommer, slik som astma og eksem, og redaktørens artikkel om hvordan man går frem for å finne årsaken ved epidemiske utbrudd av astma.

I de øvrige artiklene tar forfatterne for seg kjente sykdomsgrupper som har en velkjent eller mistenkt sammenheng med eksponering i spesielle arbeidsmiljøer. Eksempler på dette er sykdommer i kullgruveindustrien, kolonisering med MRSA som yrkesrisiko hos bønder i noen land, eller økt forekomst og dødelighet av pneumoni hos sveisere eller andre metallrøykeksponerte. Nyere problemer som sykdom hos soldater etter internasjonale oppdrag, hos gjestearbeidere eller hos eldre arbeidstakere er også behandlet.

Alt $i$ alt er dette en nyttig og oppdatert artikkelsamling, men den egner seg best som oppslagsbok, i mindre grad for lesing fra perm til perm.

\section{Tor Brøvig Aasen}

Avdelingsoverlege, Yrkesmedisinsk avdeling

Haukeland universitetssykehus 